\title{
PENGARUH MODEL PEMBELAJARAN COOPERATIVE TIPE NUMBERED HEAD TOGETHER (NHT) TERHADAP HASIL BELAJAR BIOLOGI MATERI KINGDOM ANIMALIA PADA SISWA KELAS X SMA NEGERI 4 MAROS
}

\author{
Nurdiana \\ Universitas Muslim Maros, nurdianahmad43@gmail.com
}

\begin{abstract}
Abstrak
Nurdiana 2020. Pengaruh Model Pembelajaran Cooperative Tipe Numbered Head Together (NHT) Terhadap Hasil Belajar Biologi Materi Kingdom Animalia Pada Siswa Kelas X SMA Negeri 4 MAROS, (dibimbing oleh A. Muhajir Nasir dan Novalia Tanasy). Penelitian ini termasuk penelitian Pre-Experimental Designs. Penelitian ini bertujuan untuk mengetahui bagaimana pengaruh Model Pembelajaran Cooperative Tipe Numbered Head Together (NHT) terhadap hasil belajar biologi materi kingdom animalia pada siswa kelas X SMA Negeri 4 Maros. Variabel bebas dalam penelitian ini adalah Cooperative Tipe Numbered Head Together (NHT) sedangkan variabel terikat dalam penelitian ini adalah hasil belajar biologi. Pengambilan sampel dilakukan dengan menggunakan teknik Purposive Sampling. Sampel penelitian ini adalah siswa kelas X MIPA 4 sebagai kelas Eksperimen. Data dianalisis menggunakan Analisis Uji Deskriptive, Normalitas, dan Ngain dengan menggunakan SPSS versi 16. Pada penelitian ini dapat disimpulkan bahwa ada pengaruh penggunaan Model pembelajaran Cooperative Tipe Numbered Head Together (NHT) terhadap hasil belajar biologi. Hal ini juga dibuktikan dari hasil perolehan pengujian hipotesis Ngain dengan menggunakan Gain ternormalisasi One Sample t-test yang diperoleh nilai $t_{\text {hitung }}=2.919$ dengan nilai- $p=.008$ $<\frac{1}{2} \alpha=0,025$ berarti terdapat perubahan yang signifikan. Pada posttest juga memperlihatkan bahwa 21 dari 24 peserta didik (87,5\%.) telah mencapai nilai Kriteria Ketuntasan Minimal (KKM) pada mata pelajaran biologi di SMA Negeri 4 Maros . hasil penelitian ini menunjukkan bahwa bahwa penggunaan model pembelajaran Cooperative Tipe Numbered Head Together (NHT) berpengaruh terhadap hasil belajar biologi materi Kingdom Animalia pada siswa kelas X SMA Negeri 4 Maros.
\end{abstract}

Kata Kunci: Cooperatif Tipe Numbered Head Together (NHT), hasil belajar.

\begin{abstract}
Nurdiana 2020. The Effectiveness of Cooperative Learning Model Type Numbered Head Together (NHT) Against Biology Learning Outcomes of Kingdom Animalia Material in Class X Students of SMA Negeri 4 MAROS, (supervised by A. Muhajir Nasir and Novalia Tanasy).

This research was a Pre-Experimental Designs research. The aim of this study was to find out how the influence of the Numbered Head Together (NHT) Cooperative Learning Model on the learning outcomes of kingdom animalia material biology in class X students of SMA Negeri 4 Maros. The independent variable in this study was the Cooperative Type Numbered Head Together (NHT) while the dependent variable in this study was the result of learning biology. The sampling was done by using purposive sampling
\end{abstract}


technique. The sample of this study was students of grade X MIPA 4 as an Experiment class. Data were analyzed by using Descriptive Test Analysis, Normality, and $\mathrm{N}$ gain using SPSS version 16. This study concludes that there is an influence of the use of Cooperative Type Numbered Head Together (NHT) learning model on biology learning outcomes. This also evidenced from the results of obtaining the Ngain hypothesis testing using the normalized Gain of One Sample t-test obtained by tcount $=2,919$ with $p$-value $=.008<\square(1 @ 2) \alpha=0.025$ means there is a significant change. The posttest also showed that 21 out of 24 students $(87.5 \%$.) had achieved the Minimum Mastery Criteria (KKM) value in biology in State High School 4 Maros. The result of this study indicates that the use of Cooperative learning model Numbered Head Together (NHT) affects the learning outcomes of Kingdom Animalia material biology in class X students of SMA Negeri 4 Maros.

Keywords: Cooperative Type Numbered Head Together (NHT), learning outcomes.

\section{PENDAHULUAN}

Pendidikan merupakan salah satu aspek penting bagi kehidupan manusia. Pendidikan yang berkualitas sangat diperlukan untuk mendukung terciptanya manusia yang cerdas serta mampu bersaing di era globalisasi. Pendidikan mempunyai peranan yang sangat besar dalam membentuk karakter, perkembangan ilmu dan mental seorang anak, yang nantinya akan tumbuh menjadi seorang manusia dewasa yang akan berinteraksi dan melakukan banyak hal terhadap lingkungannya, baik secara individu maupun sebagai makhluk sosial (Sukmayasa, Lasmawan, \& Sariyasa, 2013, hal. 2).

Proses pembelajaran siswa sangat berpengaruh terhadap keberhasilan belajar siswa. Salah satu faktor yang sangat mendukung adalah peran guru yang mampu menguasai dan menerapkan metode dan model pembelajaran yang tepat. Kualitas guru yang bermutu akan menyebabkan tujuan pembelajaran dapat tercapai. Kualitas pembelajaran adalah kualitas kegiatan pembelajaran yang dilakukan dan menyangkut model pembelajaran yang digunakan. Model pembelajaran merupakan prosedur sistematis dalam mengorganisasikan pengalaman belajar untuk mencapai tujuan belajar. Karena proses belajar siswa sangat dipengaruhi oleh emosi. Apabila siswa merasa terpaksa dalam mengikuti suatu pelajaran, mereka akan kesulitan untuk menerima pelajaran atau materi-materi yang diberikan oleh guru. Maka dari itu, guru harus dapat menciptakan suasana yang kondusif dan membuat pembelajaran menjadi efektif dan menyenangkan. Agar pembelajaran menyenangkan, perlu adanya perubahan 
cara mengajar dari model pembelajaran tradisional menuju model yang inovatif (Fajriyati, Supandi, \& Rahmawati, 2019, hal. 57).

Rendahnya hasil belajar siswa merupakan salah satu masalah dalam pembelajaran di sekolah. Salah satunya pada pelajaran Biologi. Karena keberhasilan pembelajaran yang dilakukan dalam kegiatan belajar mengajar dapat dilihat dari hasil belajar siswa. Hasil belajar merupakan hasil yang dicapai oleh siswa atau seseorang setelah melakukan kegiatan belajar. Siswa berusaha mendapatkan hasil belajar yang terbaik untuk mencapai prestasi yang tinggi. Hasil belajar siswa tidak hanya dilihat dari nilai akademis di sekolah saja tetapi juga dilihat dari perubahan-perubahan dalam diri siswa mengalami proses belajar mengajarnya sebagai proses perubahan yang terjadi dalam diri siswa tersebut, karena dalam kegiatan belajar mengajar siswa mengalami proses belajar mengajar sebagai proses perubahan yang terjadi dalam diri siswa akibat pengalaman yang diperoleh siswa saat berinteraksi dengan lingkungannya. Motivasi belajar juga dapat berpengaruh dalam prestasi belajar siswa. Siswa yang termotivasi tinggi dalam belajar memungkinkan akan memperoleh hasil belajar yang tinggi pula, artinya semakin tinggi motivasinya, semakin intensitas usaha dan upaya yang dilakukan, maka semakin tinggi hasil belajar yang diperolehnya. Dengan itu, motivasi belajar adalah dorongan dari dalam diri individu baik disadari maupun tidak disadari untuk melakukan perilaku belajar ke arah suatu tujuan yang ingin dicapai (Fajriyati, Supandi, \& Rahmawati, 2019, hal. 58).

Berdasarkan peneliti yang telah dilakukan oleh Saputro dkk, 2014:736 dalam (Fajriyati, Supandi, \& Rahmawati, 2019, hal. 59) menunjukan bahwa pada kecerdasan linguistik, prestasi belajar antara siswa dengan model pembelajaran kooperatif tipe Numbered Head Together (NHT) lebih baik daripada siswa dengan model pembelajaran langsung (konvensional). Berdasarkan penelitian Larasati (2012) dalam (Pakpahan \& Riwayati, 2016, hal. 58) pada penerapan model pembelajaran kooperatif tipe Numbered Head Together terdapat peningkatan hasil belajar siswa secara individual dari nilai rata-rata keseluruhan 51,25 meningkat menjadi nilai rata-rata keseluruhan 77,19. Slavin dalam Rusman (2010: 205 206) bahwa: (1) penggunaan 
pembelajaran kooperatif (Number Head

Together) dapat meningkatkan prestasi belajar siswa dan sekaligus dapat meningkatkan hubungan sosial, menumbuhkan sikap toleransi, dan menghargai pendapat orang lain, (2) pembelajaran kooperatif dapat memenuhi kebutuhan siswa dalam berpikir kritis, memecahkan masalah, dan mengintegrasikan pengetahuan dengan pengalaman.

\section{METODE PENELITIAN}

Jenis penelitian yang digunakan adalah penelitian kuantitatif dengan metode Pre-experimental Designs.

Desain penelitian ini menggunakan One-Group Pretest-posttest Design. Pada design ini terdapat pretest, sebelum diberikan perlakuan. Dengan demikian hasil perlakuan dapat diketahui lebih akurat, karena dapat membandingkan dengan keadaan sebelum diberi perlakua. (Sugiyono, 2017, hal. 110).

Penelitian yang digunakan adalah bentuk penelitian Pre-experimental Design dengan bentuk desain penelitian One-Group Pretest-posttest Design yang dapat digambarkan sebagai berikut:

$\begin{array}{lll}\mathrm{O}_{1} & \mathrm{X} & \mathrm{O}_{2}\end{array}$

Keterangan :

$\mathrm{O}_{1}=($ pretest $)$ tes awal

$\mathrm{O}_{2}=($ posttest $)$ tes akhir
$\mathrm{X}=$ Perlakuan menggunakan model cooperative tipe NHT

Sumber: (Sugiyono, 2017).

Populasi dalam penelitian ini adalah seluruh siswa kelas X MIPA SMA Negeri 4 Maros Tahun Ajaran 2019/2020. Gambaran jumlah populasi pada kelas X MIPA SMA Negeri 4 Maros dapat dilihat pada tabel berikut:

\begin{tabular}{ll}
\hline Kelas & Jumlah \\
\hline X MIPA 1 & 33 orang siswa \\
X MIPA 2 & 33 orang siswa \\
X MIPA 3 & 33 orang siswa \\
X MIPA 4 & 32 orang siswa \\
X MIPA 5 & 33 orang siswa \\
X MIPA 6 & 33 orang siswa \\
\hline Jumlah & 197 orang siswa \\
\hline
\end{tabular}

Sampel yang diambil dalam penelitian ini hanya satu kelas yaitu kelas X MIPA 4 berjumlah 32 siswa. Dalam pengambilan kelas eksperimen, teknik sampling yang digunakan adalah teknik Purposive sampling.

\section{HASIL DAN PEMBAHASAN}

Penelitian ini di laksanakan di SMA Negeri 4 Maros yaitu kelas $\mathrm{X}$ MIPA 4 dengan jumlah siswa 32 orang. Penelitian ini dilakukan untuk mengetahui hasil belajar siswa diberikan perlakuan yaitu penggunaan model pembelajaran Cooperative Tipe Numbered Head Together (NHT) pada kelas eksperimen. Penerapan model pembelajaran tersebut di khususkan pada materi Kingdom Animalia. Hasil 
penelitian ini menggambarkan hasil belajar siswa sebelum dan sesudah di berikan perlakuan.

Penelitian ini dilakukan sejak tanggal 15 mei s/d 20 mei 2020 yaitu sebanyak 3 kali pertemuan. Jenis tes yang diberikan adalah pilihan ganda dengan 20 butir soal yang telah divalidasi. Pemberian pretest kepada peserta didik dilakukan pada pertemuan pertama sedangkan pemberian posttest kepada siswa dilakukan pada pertemuan ketiga.

Untuk mengetahui keadaan awal hasil belajar siswa kelas X MIPA 4 SMA Negeri 4 Maros dilakukan pretest sebelum diterapkan model pembelajaran Cooperative Tipe Numbered Head Together (NHT). Berikut merupakan nilai dan hasil analisis deskriptif dari data pretest pada kelas X MIPA 4 SMA Negeri 4 maros dengan menggunakan bantuan aplikasi (SPSS) versi 16 dan untuk mengetahui gambaran umum dari data pretest yang ditampilkan melalui tabel berikut ini:

Tabel 4.1 Rekapitulasi Hail Belajar Pretest

\begin{tabular}{|c|c|c|}
\hline Kategori nilai statistic & Pretest & Pada tabel 4.3 dapat dilihat \\
\hline Jumlah sampel & 24 & bahwa skor tertinggi hasil belajar siswa \\
\hline Nilai Tertinggi & 85 & \\
\hline Nilai Terendah & 40 & setelah diterapkan model pembelajaran \\
\hline Rata-rata & 65,21 & Cooperative \\
\hline Standar Deviasi & 12,38 & \\
\hline
\end{tabular}

Pada tabel 4.1 dapat dilihat bahwa skor nilai tertinggi hasil belajar siswa sebelum diterapkan model pembelajaran Cooperative Tipe Numbered Head Together (NHT) yaitu 85 serta nilai terendah yaitu 40, nilai rata-rata adalah 65, 21 nilai Standar Deviasi 12,38 .

Untuk mengetahui keadaan akhir hasil belajar siswa kelas X MIPA 4 SMA Negeri 4 Maros dilakukan posttest pada materi Kingdom Animalia. Berikut merupakan nilai dan hasil analisis deskriptif dari data posttest pada kelas X MIPA 4 SMA Negeri 4 Maros dengan menggunakan bantuan aplikasi Statistical package the social sciences (SPSS) versi 16 dan untuk mengetahui gambaran umum dari data posttest yang ditampilkan melalui tabel berikut ini:

Tabel 4.2 Rekapitulasi hasil belajar posttest

\begin{tabular}{ll}
\hline $\begin{array}{c}\text { Kategori nilai } \\
\text { Statistik }\end{array}$ & \multicolumn{1}{c}{ Posttest } \\
\hline Jumlah sampel & 24 \\
Nilai Tertinggi & 95 \\
Nilai Terendah & 70 \\
Rata-rata & 81,67 \\
Standar Deviasi & 7,47 \\
\hline Sumber: Analisis data dengan SPSS 16, 2020)
\end{tabular}


terendah adalah 70 , sedangkan nilai ratarata adalah 81,67 nilai standar Deviasi 7,47 .

Berdasarkan deskripsi hasil belajar siswa baik pretest maupun posttest, maka hasil belajar siswaa setelah di ajar menggunakan model pembelajaran Cooperative Tipe Numbered Head Together (NHT) pada kelas eksperimen dalam penelitian ini dapat dikatakan meningkat. Dengan kata lain, hasil belajar siswa setelah diberi perlakuan berbeda dengan hasil belajar siswa sebelum diberi perlakuan. Perbedaan tersebut menunjukkan adanya peningkatan hasil belajar siswa.

Adapun untuk ketuntasan belajar siswa berdasarkan aturan yang telah ditetapkan di SMA Negeri 4 Maros pada kelas X. Nilai siswa dikatakan tuntas pada mata pelajaran Biologi jika mencapai nilai ketuntasan 75. Setelah siswa diajar dengan menggunakan model pembelajaran Cooperative Tipe Numbered Head Together (NHT) terdapat 21 dari 24 siswa yang mencapai nilai ketuntasan, atau dengan kata lain ketuntasan hasil belajar siswa yang dicapai pada kelas eksperimen sebesar $87,5 \%$.

Berdasarkan analisis deskriptif, terlihat bahwa penggunaan model pembelajaran Cooperative Tipe Numbered Head Together (NHT) terhadap hasil belajar biologi materi Kingdom Animalia memberikan pengaruh yang positif terhadap hasil belajar biologi. Pengaruh tersebut dapat dijelaskan dari nilai rata-rata tes hasil belajar yang di ukur melalui tes awal (pretest) sebelum siswa diberi perlakuan dan tes akhir (posttest) setelah siswa diberi perlakuan.

Nilai rata-rata hasil belajar siswa pada pretest adalah 65,21 berdasarkan deskripsi hasil belajar siswa pada hasil pretest masih dalam kategori sedang. Kemudian nilai rata-ratanya meningkat menjadi 81,67 pada posttest di akhir pembelajaran yang berdasarkan kriteria hasil belajar berada pada kategori tinggi. Salah satu faktor yang menyebabkan hasil belajar siswa meningkat adalah diterapkannya model pembelajaran Cooperative Tipe Numbered Head Together (NHT). Pada posttest juga memperlihatkan bahwa 21 dari 24 siswa atau dengan kata lain 87,5\% siswa telah mencapai nilai Kriteria Ketuntasan Minimal (KKM) pada mata pelajaran Biologi di SMA Negeri 4 maros yaitu 75 .

Selain itu, analisis inferensial juga menunjukkan fakta bahwa uji one sample t-test dengan taraf signifikansi $\alpha=$ 
0,05, diperoleh nilai sig (2-tailed) yakni .008. Karena Sig (2-tailed) $<\frac{1}{2} \alpha$ atau 0,025, sesuai dengan kaidah pengujian hipotesis ini maka diketahui bahwa terdapat peningkatan yang signifikan terhadap hasil belajar siswa Kelas X MIPA 4 SMA Negeri 4 Maros setelah diajar dengan menerapkan model pembelajaran Cooperative Tipe Numbered Head Together (NHT).

Kelebihan model pembelajaran Cooperative Tipe Numbered Head Together (NHT) terhadap hasil belajar biologi materi Kingdom Animalia adalah setiap siswa menjadi siap, dapat melakukan diskusi dengan sungguhsungguh ketika proses diskusi sedang berlangsung, kemudian siswa yang dipilih untuk memaparkan materi kelompoknya memiliki tanggung jawab terhadap kelompoknya. Melalui model pembelajaran Cooperative Tipe Numbered Head Together (NHT) diharapkan dapat membantu untuk mempermudah siswa dalam memahami materi yang disampaikan sehingga dapat meningkatkan hasil belajar siswa.

Penggunaan model pembelajaran Cooperative Tipe Numbered Head Together (NHT) terhadap hasil belajar biologi materi Kingdom Animalia yang diterapkan dapat membantu mengatasi masalah yang ditemukan penelitian dalam mengajarkan materi Kingdom Animalia. Dengan penggunaan model pembelajaran Cooperative Tipe Numbered Head Together (NHT) yang dapat menarik siswa, sehingga siswa menunjukkan minat belajar yang respontif, dimana dalam pembelajaran tersebut peserta didik sangat antusias dengan model pembelajaran Cooperative Tipe Numbered Head Together (NHT). Selama proses belajar mengajar tersebut berlangsung mampu membangkitkan minat belajar mereka terhadap materi yang diajarkan.

Fakta yang ditemukan peneliti pengaruh model pembelajaran Cooperative Tipe Numbered Head Together (NHT) sebelumnya pernah dilakukan oleh Nirnawati dengan judul "Peningkatan Hasil Belajar IPA Biologi Melalui Metode Kooperatif Tipe Numbered Head Together (NHT) Pada Siswa Kelas VII SMPN 23 SIMBANG". Kesimpulan dari penelitian ini bahwa penerapan model pembelajaran kooperatif Tipe Numbered Head Together (NHT) dapat meningkatkan hasil belajar biologi pada siswa kelas VII SMPN 23 Simbang. Hal ini terlihat dari nilai rata-rata tes tes akhir sebesar 70,17 pada siklus I menjadi 77,6 pada siklus II 
dari skor ideal 100. Hasil belajar siswa kelas VII SMPN 23 Simbang pada siklus II mengalami peningkatan lebih baik dari siklus sebelumnya. Hal ini dapat ditunjukkan terjadinya peningkatan ketuntasan belajar pada siklus I sebesar 46,66\% menjadi $90 \%$ pada siklus II.

Berdasarkan uraian di atas dapat disimpulkan bahwa pembelajaran dengan menerapakan Model Pembelajaran Cooperative Tipe Numbered Head Together (NHT) Terhadap Hasil Belajar Biologi Materi Kingdom Animalia Pada Siswa Kelas X SMA Negeri 4 Maros dapat meningkatkan hasil belajar peserta didik.

\section{KESIMPULAN}

Berdasarkan hasil analisis dan pembahasan yang telah dilakukan pada Bab IV, maka peneliti mengambil simpulan sebagai berikut:

Hasil belajar sebelum diterapakan model pembelajaran Cooperative Tipe Numbered Head Together (NHT) pada materi Kingdom Animalia dapat diketahui bahwa nilai rata-ratanya sebesar 65,21 dan ketuntasan klasikalnya $70,83 \%$. Dimana, rata-rata hasil belajar tersebut kurang dari $75 \%$ dan ketuntasan klasikalnya belum mencapai $75 \%$. Sehingga dapat dikatakan bahwa hasil belajar tersebut belum memenuhi Kriteria Ketuntasan Minimal (KKM) yang ditentukan. Hasil belajar setelah diterapkan model pembelajaran Cooperative Tipe Numbered Head Together (NHT) dengan materi Kingdom Animalia dapat diketahui bahwa nilai rata-ratanya sebesar 81,67 dan ketuntasan klasikalnya 87,5\%. Dimana, rata-rata hasil belajar tersebut lebih dari $75 \%$ dan ketuntasan klasikalnya berada diatas $75 \%$. Sehingga dapat dikatakan bahwa hasil belajar tersebut sudah memenuhi Kriteria Ketuntasan Minimal (KKM) yang ditentukan.

\section{UCAPAN TERIMA KASIH}

Secara khusus penulis mengucapkan terima kasih yang sebesar besarnya kepada kedua orang tuaku, kepada ibu hj. Halina terima kasih yang sebesar besarnya atas segala do'a, dukungan dan kepoercayaan yang telah diberikan kepada saya, dan terima kasih kepada bapak Hamma terima kasih sebesar besarnya atas setiap cucuran keringatmu dalam menafkahi dan membimbingku, dan terima kasih atas segala do'a dan dukungannya. 


\section{DAFTAR PUSTAKA}

Baharuddin, N. (2015). Teori Belajar dan Pembelajaran. Yogyakarta: Ar-Ruzz Media.

Cahyati, \& kartika. (2019). Pengaruh Model Cooperative Lerning Tipe Numbered Head Together (NHT) dengan Metode Tutor Sebaya (Peer Tutoring) Terhadap Peningkatan Hasil Belajar Siswa Kelas X MAN 4 Bantul pada Materi Momentum, Impuls dan Tumbukan. Jurnal Penelitian Pembelajran

FisikaVol.10.Online.Diunduh pa da $10 \quad$ november,http// journal.upgris.ac.id

Fajriyati, R.,Supandi, \& Rahmawati, N.D. (2019). Efektivitas model pembelajaran kooperatif tipe group investigation (GI) dan numbered head together (NHT) terhadap prestasi belajar matematika. Jurnal Matematika dan Pendidikan Matematika:Vol 1:No 4.

Fathurrohm an, M. (2015). Model-model Pembelajaran Inovatif. Jogjakarta: Ar-Ruzz Media.

Manurung, I. W., Mulyani, B., \& Saputro, S. (2013). Pengaruh penggunaan model pembelajaran koperatif numbered head together (NHT) dan learning together (lt) dengan melihat kemampuan memori siswa terhadap prestasi belajar siswa pada materi tata nama senyawa kimia kelas $\mathrm{x}$ sma negeri 2 karanganyar. Jurnal Pendidikan Kimia (JPK): Vol 2:No.4, 25.

Nur, M. I., Salam, M., \& Hasnawati. (2016). Pengaruh Penerapan
Model Pembelajaran Kooperatif Tipe Numbered Heads Together (NHT) Terhadap Hail Belajar Matematika Siswa Kelas VII Smp Negeri 1Tongkuno . Jurnal Penelitian Pendidikan Matematika Volume 4.Online. Diunduh pada 12 november http//osj.unho.ac.id/index.php/JP PM/article/view/3055

Pakpahan, M., \& Riwayati. (2016). Perbedaan Hasil Belajar Menggunakan Model Pembelajaran Numbered Head Together (NHT) dengan Think Pair Share (TPS) pada Materi Ekosistem di Kelas VII. JURNAL PELITA PENDIDIKAN VOL. 4 NO. 2.

Pietersz, F., \& Saragih, H. (2010). Pengaruh Penggunaan Pembelajaran Kooperatif Tipe Numbered Head Together Terhadap Pencapaian Matematika di SMP Negeri 1 Cisarua. 433.

Rusman. (2013). Model-model pembelajaran:Mengembangkan profesionalisme guru. Jakarta: Rajawali pers.

Sastrawan, W., Sedanayasa, G., \& Suwatra, I. W. (2014). Pengaruh Model Pembelajaran Kooperatif Tipe Numbered Heads Together (NHT) dengan Bantuan Media Software Pembelajaran Terhadap Hasil Belajar IPA Siswa Kelas V SD GUGUS III DESA BENGKEL KECAMATAN BUSUNGBIU. Jurnal Mimbar PGSD Universitas Pendidikan Ganesha: Vol: 2 No: 1 Tahun, 2 
Sudjana, Nana. Penilaian Hasil Proses Belajar Mengajar.Bandung: PT. Remaja Rosdakarya, 2008.

Sugiyono. (2017). Metode Penelitian Pendidikan. Bandung: Alfabeta.

Sukmayasa, M. H., Lasmawan, I. W., \& Sariyasa. (2013). Pengaruh Model Pembelajaran Kooperatif Tipe NHT Berbantuan Senam Otak Terhadap Keaktifan dan Prestasi Belajar Matematika. Jurusan Pendidikan Dasar Volume 3, 2.

Shoimin, A. (2016). 68 Model Pembelajaran Inovatif dalam Kurikulum 2013. Yogyakarta : Ar-Ruzz Media.

Syarifatunnisa, Suradi, \& Awi. (2019). Perbandingan hasil belajar matematika siswa dengan menggunakan model pembelajaran kooperatif antara tipe TGT ( Teams Games Tournament) dan Tipe NHT
(Numbered Head Together) ditinjau dari kecerdasan Interpersonal siswa. Issues in mathematics

Education:Vol.3:No.1,

41.Online. Diunduh pada 13 Desember https://osj.unm.ac.id/imed/article/ view/10734.

Tanjung, I. F. (2016). Pengaruh Model Pembelajaran Kooperatif Tipe Think Pair Share (TPS) dan Numbered Heads Together (NHT) Terhadap Hasil Belajar Biologi Siswa Madrasah Aliyah Negeri 1 Medan . Jurnal Pendidikan Islam dan Teknologi Pendidikan vol.VI, no 1, 5.online. Diunduh pada 10 November dari http://jurnaltarbiya h.uinsu.ac.id/index.php/nizhamiyah /article/view/24 